\title{
The role of extracorporeal membrane oxygenation in patients after irreversible cardiac arrest as potential organ donors
}

\author{
Tomasz Kłosiewicz ${ }^{1,2}$, Mateusz Puślecki ${ }^{1,3}$, Marcin Zieliński ${ }^{1,4}$, Michał Mandecki ${ }^{1}$, Marcin Ligowski ${ }^{3}$, \\ Sebastian Stefaniak ${ }^{3}$, Marek Dąbrowski ${ }^{1,2}$, Marek Karczewski ${ }^{1}$, tukasz Gąsiorowski ${ }^{2,5}$, Maciej Sip ${ }^{1,2}$, \\ Agata Dąbrowska ${ }^{1,2}$, Wojciech Telec ${ }^{1}$, Bartłomiej Perek ${ }^{3}$, Marek Jemielity ${ }^{3}$ \\ ${ }^{1}$ Department of Medical Rescue, Poznan University of Medical Sciences, Poland \\ ${ }^{2}$ Polish Society of Medical Simulation, Poland \\ ${ }^{3}$ Department of Cardiac Surgery and Transplantology, Poznan University of Medical Sciences, Poland \\ ${ }^{4}$ Poznan Emergency Medical Service, Poland \\ ${ }^{5}$ Department of Emergency Medicine, Poznan University of Medical Sciences, Poland
}

Kardiochirurgia i Torakochirurgia Polska 2017; 14 (4): 253-257

\begin{abstract}
The number of people waiting for a kidney or liver transplant is growing systematically. Due to the latest advances in transplantation, persons after irreversible cardiac arrest and confirmation of death have become potential organ donors. It is estimated that they may increase the number of donations by more than $40 \%$. However, without good organization and communication between pre-hospital care providers, emergency departments, intensive care units and transplantation units, it is almost impossible to save the organs of potential donors in good condition. Various systems, including extracorporeal membrane oxygenation (ECMO), supporting perfusion of organs for transplantation play a key role. In 2016 the "ECMO for Greater Poland" program was established. Although its main goal is to improve the survival rate of patients suffering from life-threatening cardiopulmonary conditions, one of its branches aims to increase the donation rate in patients with irreversible cardiac arrest. In this review, the role of ECMO in the latter group as the potential organ donors is presented. Key words: transplantation, organ donor, cardiac arrest.
\end{abstract}

\section{Streszczenie}

Liczba osób czekających na przeszczep nerki czy wątroby stale wzrasta. Dzięki postępowi w transplantologii osoby z nieodwracalnym zatrzymaniem krążenia, które uznaje się za zmarłe, mogą zostać potencjalnymi dawcami narządów. Wykazano, że grupa ta może zwiększyć aktywność donacyjną o 40\%. Jednak bez odpowiedniej organizacji lokalnego systemu ochrony zdrowia oraz komunikacji między strukturami ratownictwa przedszpitalnego, szpitalnymi oddziałami ratunkowymi, oddziałami intensywnej terapii oraz specjalistami z dziedziny transplantologii prawie niemożliwe jest uzyskanie organów dobrej jakości. Różne systemy wspomagania krążenia, w tym pozaustrojowa oksygenacja membranowa (ECMO), które jednocześnie wspierają funkcje narządów przeznaczonych do transplantacji, odgrywają dużą rolę. W 2016 r. w Poznaniu utworzono program „ECMO dla Wielkopolski”. Jego głównym zadaniem jest poprawa przeżywalności osób w stanie zagrożenia życia z powodu nagłej dysfunkcji układów sercowo-naczyniowego oraz oddechowego. Jedną z gałęzi programu jest zwiększenie donacji narządów od pacjentów po nieodwracalnym zatrzymaniu krążenia. W pracy przedstawiono możliwości wykorzystania ECMO w tej grupie chorych - potencjalnych dawców organów.

Słowa kluczowe: transplantacja, dawstwo narządów, zatrzymanie krążenia.

In Poland in the last few years approximately 1000 kidney transplantations have been performed each year, and at least twice as many have been on the waiting lists. Despite the improvement in transplant coordination, employment of trained coordinators in many hospitals and media activities, still many patients die waiting for an organ trans-

Address for correspondence: Tomasz Kłosiewicz MSc, Department of Medical Rescue, Poznan University of Medical Sciences, 79 Dabrowskiego St, 60-529 Poznan, Poland, phone: +48 668956 969, e-mail: klosiewicz.tomek@gmail.com Received: 12.09.2017, accepted: 26.11.2017. 
plant. Moreover, we have not observed an increase in the number of identified donors ex mortuo brain death in Poland for many years. In 2009 it amounted to 11 donors per million inhabitants, while in 2015 it was 13.6. Moreover, the average waiting time for first kidney transplantation was 10 months after placement on the waiting list and more than 2.5 years after dialysis initiation [1, 2]. This shortage of organ donors is not an isolated phenomenon in Poland. In other European countries, despite the much greater numbers of organs transplanted each year (from 23.4 donors per 1 million inhabitants in the Czech Republic to more than 40 per million in Spain), intensive care specialists and transplantologists are searching for more opportunities to increase the number of organ procurements and transplantations. One intriguing option is the inclusion in the transplantation program of donors after irreversible cardiac arrest (donors after circulatory death - DCD) in whom the circulatory criteria are applied to define death. So far, DCD donation programs have been successfully implemented in many countries (Spain, Italy, the Netherlands, France, Switzerland, USA) [3].

Interruption of central nervous system functions begins at the time of sudden cardiac arrest (SCA). Increasing hypoxia and deepening metabolic acidosis lead to many irreversible changes at the cellular level. Thus transplantation of organs from DCD is still a complex procedure from the perspective of time, optimal organization and technological challenges. This makes transplants even more difficult, and this fact prohibits the widespread use in Poland, in contrast to other countries $[4,5]$. The survival of SCA victims depends on the response time of random bystanders' chest compressions, rapid defibrillation, advanced life support and postresuscitation care. This rate still remains low at 7.6\% [6].

The aim of this work is to review the new opportunities of transplantation supported by application of available methods of extracorporeal perfusion (circulation and oxygenation), particularly extracorporeal membrane oxygenation (ECMO), in patients with irreversible cardiac arrest.

\section{Rationale to use extracorporeal circulation}

After unsuccessful treatment of SCA and considering all potentially reversible causes, the persons can be regarded as dead donors diagnosed according to the circulatory criteria. Liver and kidney cells are more resistant to hypoxia than brain cells. Organs from DCD retain a long period of warm ischemia time (WIT) that is defined as the period between the SCA of donors and cold preservation of the donated organs. The suitability of donor organs declines rapidly and warm ischemic damage might lead the grafts to primary or delayed function recovery. To minimize ischemic time it is important to shorten the WIT and to perfuse organs with oxygenated blood until their procurement. Although the idea of perfusion of donated organs is relatively old (Marchiaro 1963) [7], the first description of clinical use of hypothermic ECMO in DCD to preserve kidneys was published more than 20 years later [8]. In the 1990s, other authors suggested the beneficial effects of normothermic reperfusion with the donor's blood to restore the energetic status of the cells in a pig liver transplantation model $[9,10]$. By connecting DCD to ECMO, physicians are able to maintain proper oxygenation and perfusion of organs for donations. In this setting, transplantation is a very complex procedure that requires a series of laboratory tests, preparation of both a donor and a recipient, not uncommonly difficult conversation with the DCD family and completion of the obligatory documents. The best results were achieved when kidneys were donated in less than $4 \mathrm{~h}$ after cardiac arrest in DCD but without ECMO. Extracorporeal membrane oxygenation provides the possibility to extend the safe time of proper organ preservation. Other proven advantages of ECMO perfusion include better assessment of organ function before procurement and the procurement procedure becomes semi-elective. However, the mandatory condition is to start organ perfusion earlier than 150 min after SCA. By using this method, the number of kidney donations, in countries where is implemented, has increased even up to 44\% [11]. In Europe, the leading centers in the transplantation of organs from DCD are in Spain and the United Kingdom. For example, only in Madrid in 2009, 148 kidneys, 20 livers and 3 lungs were transplanted applying this strategy [12].

Not only the number of transplanted organs matters but also their function after transplantation. Valero et al. proved that the normothermic recirculation reduces primary graft dysfunction of kidneys obtained from nonbeating heart donors [13]. Normothermic ECMO (nECMO) was shown to decrease markedly the rate of delayed graft function (DGF) [14]. Farney et al. observed 20\% incidence of DGF in ECMO-assisted DCD compared to approximately $60 \%$ in non-supported cases [15]. The recent meta-analysis performed by Akoh revealed at least comparable outcomes at 1 and 5 years after renal transplantation from DCD vs. donors after brain death (DBD) [16]. Some studies underlined the advantages of DCDs in which the donation process was relatively fast. The prolonged stay in the intensive care room is unfavorable because of increased risk of infections. Additionally, the body in DCD cases is not devoid of neurological regulation for such a long period as is the case in DBD [15]. Worse early results and delayed graft function were reported in DCD on automated chest compression (ACC) than DCD on nECMO. A significant improvement in results was observed with $n E C M O$, although DCD has poorer early graft function but equivalent long-term performance $[17,18]$.

Extracorporeal membrane oxygenation has not been used for DCD donations in order to increase the pool of organs in Poland yet. Thus the project called "ECMO for Greater Poland" was created. The aim of "ECMO for Greater Poland" was to create a system-wide procedure to identify potential candidates for extracorporeal oxygenation and transport to specialized medical centers in order to implement the therapy and continue to the highest possible level. Among many arms, the DCD-ECMO one was designed to increase the number of potential organs that can be used 
for transplantation. For the purposes of implementation, the program was divided into overlapping steps (cells) that made up a well-functioning "ECMO chain of survival". The consecutive steps are: pre-hospital, hospital, perfusion and transplantation [19, 20] (Fig. 1).

\section{Legislation and inclusion criteria}

As DCD is a very sensitive matter it must be enabled by official legislation. Organ donation after irreversible SCA in the proceedings ex mortuo donation, possible due to Art. No. 9 of the Polish transplantation act (u.p.p.p.) after the last amendment of 17 July 2009. ("Donation of cells, tissues or organs for transplantation is allowed after discovery of death due to irreversible cardiac arrest") [21], still remains a marginalized issue in Poland.

A statement of the Ministry of Health presents the criteria and methods of termination of treatment if irreversible cardiac arrest occurs. These criteria must be met for each patient who is planned to be a potential organ donor.

- Condition I: during at least 20 min in adults (45 min in children) of CPR, asystole or pulseless electric activity (PEA) occurs.

- Condition II: PEA or asystole persists for at least 5 min after termination of CPR. If during this interval ventricular fibrillation or return of spontaneous circulation occurs, CPR must be resumed for at least another 20 min and then again withdrawn for another 5 min to repeat the evaluation.

- Condition III: If the physician states that CPR does not improve the patient's chance of survival, he starts a 5-minute observation immediately.

- Condition IV: during the 5-minute observation none of the following reactions are observed: spontaneous breathing, pupil reaction to light, corneal reflex, ocular reflex, pain reactions within the innervation of cranial and spinal nerves.

Moreover, the DCD procedure must be accompanied by the opinion of two specialists in the field of anesthesiology and intensive care, emergency medicine, cardiology, pediatric cardiology or internal medicine and then recorded in the relevant documentation.

In Poland in 2010, the Ministry of Health created the National Program for the Development of Transplantation Medicine. DCD, diagnosed according to the cardiopulmonary criteria, is based on the identification of the donor death as a result of irreversible cardiac arrest on the basis of criteria presented for the first time at a conference in Maastricht in 1995 and consists of the following groups: [1] death of donor before admission, [2] donor after unsuccessful cardiopulmonary resuscitation (CPR), [3] donor expected after cardiac arrest - the termination of futile therapy, and [4] donor with symptoms of brain death, with cardiac arrest [22].

Inclusion criteria for patients with SCA include known personality, CPR started in less than 30 min after onset of SCA symptoms, age below 60 years, known or suspected cause of death, no features of massive hemorrhage, no signs of stitches or tattoos, no risky sexual behavior, no

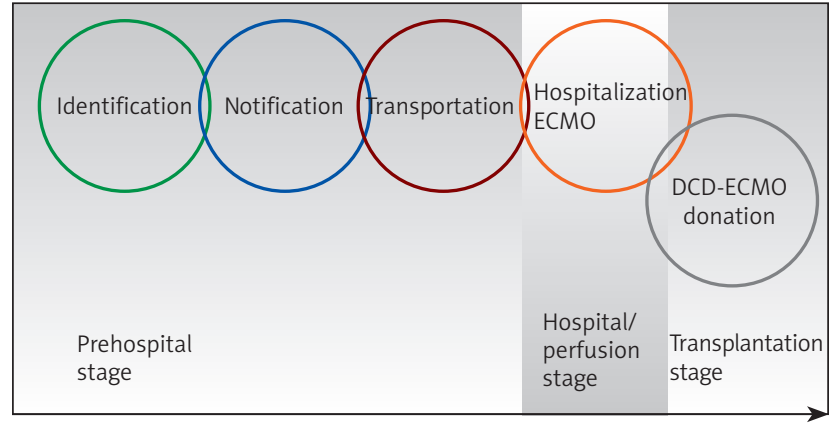

Fig. 1. ECMO chain of survival

deep hemodynamic disturbances in time up to $1 \mathrm{~h}$ before arrest, possibility of mechanical chest compression and time to cannulation of blood vessels for perfusion less than 120 min (or less than 150 min for ECMO).

\section{Transport and preparation of the patient for surgery}

In order to improve and maintain an appropriate level of solid organ perfusion, devices for automated chest compression (ACC) are used. They provide a better quality of chest compressions and increases personnel safety during transportation [23, 24]. A study from Barcelona showed that the percentage of kidneys disqualified due to inadequate perfusion during resuscitation with a Lucas ACC device was reduced by $32.9 \%$ compared to patients whose compression was performed by rescuers themselves [25]. On the basis of another study it was clearly identified that proper perfusion significantly increased the number of donations.

On admission to hospital, the assessment of potential DCD is based on the hospital protocol for the possibility of donation. The risk factors as well as the relative and absolute contraindications to organ harvest are estimated. A crucial element of DCD-ECMO is the cannulation time of blood vessels for extracorporeal circulation under normothermia, referred to as $n E C M O$. One of the modifications of the standard ECMO procedure in DCD cases is to confine perfusion to the level of the liver or kidney by means of a dedicated intra-aortic balloon. It is entered into the lumen of the aorta just above vessels supplying the aforementioned organs. Before introduction of the first ECMO cannula, heparin should be given in a dose of $1.5 \mathrm{mg} / \mathrm{kg} /$ $90 \mathrm{~min}$. This type of treatment significantly prolongs survival and organ suitability for transplantation. It helps to maintain the recirculation up to $4 \mathrm{~h}$ at a flow rate of 1.2 to $1.7 \mathrm{l} / \mathrm{m}^{2} / \mathrm{min}$ and the donor's body temperature at $35.5^{\circ} \mathrm{C}$ to $37.5^{\circ} \mathrm{C}$. During the entire procedure constant monitoring of the basic metabolic panel and arterial blood gases is required. The hematocrit level should be kept at 20-30\%. After fulfillment of all the required criteria in the procedures, preparation of the donor and recipient begins.

\section{The role of simulation}

The proper functioning of each chain of survival is crucial to succeed in DCD-ECMO. As this concept connects 
several medical pre- and in-hospital systems it requires considerable financial resources and well-educated, experienced medical staff. Thus proper and effective education is of paramount importance. High-fidelity medical simulation is a modern medical teaching method that allows medical personnel to perform all necessary procedures using advanced patient simulators. Simulation is completely safe and enables experience to be gained in complex medical procedures such as DCD-ECMO. Recently, our team has created such a simulator. It adapted the manikin by implementing a system of silicone loops and tubing mimicking blood vessels (modified polyethylene), filled with pressurized red-dyed liquid and covered by artificial skin [26, 27]. Moreover, up to know a few clinical scenarios with DCDECMO have been performed. These simulations connected all links of the chain - pre-hospital, early in-hospital, advanced in-hospital - and involved cardiac surgeons, anesthesiologists, perfusionists, critical care nurses and in one case also the transplant team [28-33].

\section{Conclusions}

Most cases of SCA end with patients' death as witnesses usually do not perform effective chest compressions. The organs of dead persons can offer help for patients with endstage organ failure waiting for transplantation. Possible application of modern techniques such as ECMO or ACC devices opens up the possibility to increase the donor pool. Although available studies suffer from methodological limitations such as small cohorts or retrospective analysis, they all reached the same conclusions that the concept of extracorporeal support with oxygenation in DCD seemed very promising. However, further studies on larger cohorts are required.

\section{Disclosure}

Authors report no conflict of interest.

\section{References}

1. Durlik M, Klinger M. Chory dializowany jako biorca przeszczepu. Forum nefrologiczne 2010; 3: 201-211.

2. POLTRANSPLANT Information Bulletin 2016; 1: 14-33.

3. Ortega-Deballon I, Hornby L, Shemie S. Protocols for uncontrolled donation after circulatory death: a systematic review of international guidelines, practices and transplant outcomes. Crit Care 2015; 19: 268.

4. Lee J, Hong S, Oh C, Hong Y, Yim H. Kidney transplantation from a donor following cardiac death supported with extracorporeal membrane oxygenation. J Korean Med Sci 2012; 27: 115-119.

5. Gravel MT, Arenas JD, Chenault R $2^{\text {nd }}$, Magee JC, Rudich S, Maraschio M, DebRoy M, Miller W, Punch JD. Kidney transplantation from organ donors following cardiopulmonary death using extracorporeal membrane oxygenation support. Ann Transplant 2004; 9: 57-58.

6. Nolan JP. Optimizing outcome after cardiac arrest. Curr Opin Crit Care 2011; 17: 520-526.

7. Marchioro TL, Huntley RT, Waddell WR, Starzl TE. Extra-corporeal perfusion for obtaining postmortem homografts. Surgery 1963; 54: 900-911.

8. Kontos GJ Jr, Adachi H, Borkon MA, Cameron DE, Baumgartner WA, Hutchins GM, Brawn J, Reitz BA. A no-flush, core-cooling technique for successful cardiopulmonary preservation in heart-lung transplantation. J Thorac Cardiovasc Surg 1987; 94: 836-842.

9. González FX, García-Valdecasas JC, Lopez-Boado MA, Tabet J, Net M, Grande L, Cifuentes A, Rull R, Valero R, Beltrán J, Elena M, Cabrer C, Palacin J, Visa J. Adenine nucleotide liver tissue concentrations from nonheart-beating donor pigs and organ viability after liver transplantation. Transplant Proc 1997; 29: 3480-3481.

10. Tabet J, García-Valdecasas JC, Net M, Cifuentes A, González FX, Valero R, Deulofeu R, Rimola A, Garcia F, Visa J. Evaluation of ischemic liver injury during graft procurement from nonheart-beating donor pigs. Transplant Proc 1997; 29: 3482-3483.

11. Lazzeri C, Bonizzoli M, Valente S, Cianchi G, Migliaccio ML, Gensini GF, Peris $A$. The role of extracorporeal membrane oxygenation in donation after circulatory death. Minerva Anesth 2014; 80: 1217-1227.

12. Matesanz R, Domínguez-Gil B, Coll E, de la Rosa G, Marazuela R. Spanish experience as a leading country: what kind of measures were taken? Transpl Int 2011; 24: 333-343.

13. Valero R, Cabrer C, Oppenheimer F, Trias E, Sánchez-Ibáńez J, De Cabo FM, Navarro A, Paredes D, Alcaraz A, Gutiérrez R, Manyalich M. Normothermic recirculation reduces primary graft dysfunction of kidneys obtained from non-heart-beating donors. Transpl Int 2000; 13: 303-310.

14. Snoeijs M, Winkens B, Heemskerk M, Hoitsma A, Christiaans M, Buurman W, van Heurn L, Ernest W. Kidney transplantation from donors after cardiac death: a 25-year experience. Transplantation 2010; 90: 1106-1112.

15. Farney AC, Singh RP, Hines MH, Rogers J, Hartmann EL, Reeves-Daniel A, Gautreaux MD, Iskandar SS, Adams PL, Stratta RJ. Experience in renal and extrarenal transplantation with donation after cardiac death donors with selective use of extracorporeal support. J Am Coll Surg 2008; 206: 1028-1037.

16. Akoh J. Kidney donation after cardiac death. World J Nephrol 2012; 1: 79-91.

17. Pine JK, Aldouri A, Young AL, Davies MH, Attia M, Toogood GJ, Pollard SG, Lodge JP, Prasad KR. Liver transplantation following donation after cardiac death: an analysis using matched pairs. Liver Transpl 2009; 15: 1072-1082.

18. Summers DM, Johnson RJ, Allen J, Fuggle SV, Collett D, Watson CJ, Bradley JA. Analysis of factors that affect outcome after transplantation of kidneys donated after cardiac death in the UK: a cohort study. Lancet 2010; 376: 1303-1311.

19. Puślecki M, Ligowski M, Dąbrowski M, Telec W, Perek B, Jemielity M. “ECMO for Greater Poland": a unique regional program for extracorporeal life support. Pol Arch Intern Med 2017; 127: 567-568.

20. Puślecki M, Ligowski M, Dąbrowski M, Stefaniak S, Gąsiorowski Ł, Dąbrowska A, Kłosiewicz T, Sip M, Zieliński M, Pawlak A, Sobczyński P, ŁukasikGłębocka M, Karczewski M, Małkiewicz T, Artyńska A, Gezela M, KielPuślecka I, Panieński P, Perek B, Ładzińska M, Ładziński P, Kiel M, Misterski M, Buczkowski P, Mrówczyński W, Telec W, Czekajlo M, Jemielity M. Unique regional program "ECMO for Greater Poland" Eur J Heart Fail 2017, http://onlinelibrary.wiley.com/doi/10.1002/ejhf.871/epdf.

21. Ustawa o zmianie ustawy o pobieraniu, przechowywaniu i przeszczepianiu komórek, tkanek i narządów oraz o zmianie ustawy - Przepisy wprowadzające Kodeks karny z dnia 17 lipca 2009, Dz. U. z 2009 r. Nr 141, poz. 1149.

22. Ridley S, Bonner S, Bray K, Falvey S, Mackay J, Manara A. UK guidance for non-heart-beating donation. Br J Anaesth 2005; 95: 592-595.

23. Perkins G, Handley A, Koster R, Castrén M, Smyth M, Olasveengen T, Monsieurs KG, Raffay V, Gräsner J, Wenzel V, Ristagno G, Soar J, Bossaert LL, Caballero A, Cassan P, Granja C, Sandroni C, Zideman DA, Nolan JP, Maconochie I, Greif R. European resuscitation council guidelines for resuscitation 2015. Resuscitation 2015; 95: 81-99.

24. Fox J, Fiechter R, Gerstl P, Url A, Wagner H, Lüscher TF, Eriksson U, Wyss CA. Mechanical versus manual chest compression CPR underground ambulance transport conditions. Acute Card Care 2013; 15: 1-6.

25. Jiménez FC, Arránz AR, Padró PP, García AS, Martín MA, Escobar SS. Use of the Lucas mechanical chest compression device in an asystolic organ donation program: effect on kidney perfusion and organ procurement and transplantation rate. Emergencias 2012; 24: 366-371.

26. Puślecki M, Kiel M, Ligowski M, Stefaniak S, Gąsiorowski Ł, Dąbrowski M, Dąbrowska A, Kłosiewicz T, Ziemak P, Perek B, Ładzińska M, Misterski M, Urbanowicz T, Stachowiak W, Buczkowski P, Czekajlo M, Jemielity M. Customization of a patient simulator for ECMO training. Qatar Medical J 2017 http://dx.doi. org/10.5339/qmj.2017.swacelso.80.

27. Puślecki M, Kiel M, Ligowski M, Dąbrowski M, Stefaniak S, Gąsiorowski Ł, Dąbrowska A, Kłosiewicz T, Sip M, Telec W, Karczewski M, Ziemak P, Perek B, Ładzińska M, Misterski M, Urbanowicz T, Stachowiak W, Buczkowski P, Czekajlo $M$, Jemielity M. Prototype of high-fidelity ECMO simulator. Eur J Heart Fail 2017; 19: 58-67.

28. Puślecki M, Ligowski M, Stefaniak S, Zieliński M, Pawlak A, Dąbrowski M, Kłosiewicz T, Sip M, Karczewski M, Małkiewicz T, Gąsiorowski L, Telec W, Ładzińska M, Ładziński P, Perek B, Misterski M, Mrówczyński W, Sobczyński P, Panieński P, Łukasik-Głębocka M, Artyńska A, Gezela M, Buczkowski P, Cze- 
kajlo $M$, Jemielity $M$. Using simulation to create a unique regional ECMO program for the greater Poland region. Qatar Med J $4^{\text {th }}$ Annual ELSO-SWAC Conference 2017: DOI:10.5339/qmj.2017.swacelso.79.

29. Puślecki $M$, Ligowski $M$, Dąbrowski $M$, Sip $M$, Stefaniak $S$, Kłosiewicz $T$, Gąsiorowski Ł, Karczewski M, Małkiewicz T, Ładzińska M, Zieliński M, Pawlak A, Dąbrowska A, Ziemak P, Perek B, Misterski M, Katarzyński S, Buczkowski P, Telec W, Kiel-Puślecka I, Kiel M, Czekajlo M, Jemielity M. High-fidelity simulation - the first DCD-ECMO procedure in Poland. Disaster Emerg Med J 2017; 2: 50-52.

30. Puślecki M, Ligowski M, Dąbrowski M, Stefaniak S, Gąsiorowski Ł, Dąbrowska A, Kłosiewicz T, Sip M, Zieliński M, Pawlak A, Sobczyński P, ŁukasikGłębocka M, Karczewski M, Małkiewicz T, Artyńska A, Gezela M, Perek B, Ładzińska M, Kiel M, Misterski M, Buczkowski P, Telec W, Czekajlo M, Jemieli-ty M. High-fidelity ECMO simulation scenarios. Eur J Heart Fail 2017; 19: 58-67.
31. Puślecki M, Ligowski M, Dąbrowski M, Karczewski M, Małkiewicz T, Stefaniak S, Gąsiorowski Ł, Zieliński M, Pawlak A, Dąbrowska A, Kłosiewicz T, Sip M, Ziemak P, Perek B, Ładzińska M, Kiel M, Misterski M, Buczkowski P, Katarzyński S, Telec W, Jemielity M. High-fidelity simulation creating DCDECMO procedure in Poland. Eur J Heart Fail 2017; 19: 58-67.

32. Puślecki M, Ligowski M, Dąbrowski M, Sip M, Stefaniak S, Kłosiewicz T, Gąsiorowski L, Karczewski M, Małkiewicz T, Ładzińska M, Zieliński M, PawlakA, Perek B, Czekajlo M, Jemielity $M$. The role of simulation to support donation after circulatory death with extracorporeal membrane oxygenation. Perfusion 2017; 32: 624-630.

33. Puślecki M, Ligowski M, Kiel M, Dąbrowski M, Stefaniak S, Maciejewski A, KielPuślecka I, Telec W, Czekajlo M, Jemielity M. ECMO therapy simulator for extracorporeal life support. Am J Emerg Med 2017, pii: S0735-6757(17)30633-2. DOI: http://dx.doi.org/10.1016/j.ajem.2017.07.082. 